GLOBAL JOURNAL OF EDUCATIONAL RESEARCH VOL 17, 2018: 97-101

COPYRIGHT@ BACHUDO SCIENCE CO. LTD PRINTED IN NIGERIA. ISSN 1596-6224

www.globaljournalseries.com; Info@globaljournalseries.com

\title{
BASIC EDUCATION CURRICULUM IN SOUTH-SOUTH NIGERIA: CHALLENGES AND OPPORTUNITIES OFQUALITY CONTENTS IN FRENCH LANGUAGE LEARNING
}

\author{
AGBOR, CATHERINE ALEX AND ASHABUA, DERICK A.
}

(Received 15, October 2018; Revision Accepted 11, December 2018)

\begin{abstract}
The modern Nigerian society is dynamic, divided into zones based on economic, political and educational resources often shared across the zones. The six geopolitical zones in Nigeria are major divisions in modern Nigeria, created during the regime of President Ibrahim, Badamasi Babangida. The Federal Government of Nigeria in accordance with its National Council on Education had earlier directed the Nigerian Educational Research and Development Council to restructure its basic education curriculum with the hope to enable the nation meet national and global developmental goals. One of the goals of the 9-year Basic Education Programme is developing in the entire citizenry a strong consciousness for education and a strong commitment to its vigorous promotion. This paper therefore, focused on Basic Education Curriculum in South-South Nigeria: challenges and opportunities of quality contents in French Language learning. It aimed at describing some key issues in Nigeria's experience on the implementation of the Basic Education Curriculum. One research question was proposed to guide the study. One hundred and eighty $(180)$ teachers were purposefully sampled for the study. Data were collected via group discussions on seven (7) curriculum themes emphasizing learner-centred educational practices. The findings reveal that the curriculum content, among others is inadequate and should be re-examined. Recommendations were made as a panacea to concrete implementation of the basic education curriculum in Nigeria.
\end{abstract}

KEYWORDS: Basic education, quality content, south-south zone

\section{INTRODUCTION/BACKGROUND}

The six geopolitical zones in Nigeria are major divisions in modern Nigeria, which are not entirely carved out based on geopolitical location, but rather states with similar cultures, ethnic groups, and common history, were classified in the same zone. They are North Central, North East, North West, South East, South South and SouthWest. The south-south geopolitical zone comprises Akwa-lbom, Bayelsa, Cross River, Delta, Edo and Rivers states. The zone occupies approximately 85,303 square kilometres. The National Population Census (NPC, 2006) put the population of the South-South States at21,014,655 (Emeh, Isangedighi, Asuquo, Kalu, Agba and Ogaboh,2011).

However, many reforms have taken place overtime, particularly in the education sector. Education is constantly presenting new ideas and innovative approaches which act to facilitate the rapid exchange of knowledge and

Agbor, Catherine Alex, Department of Arts Education University of Calabar, Calabar. Nigeria. Ashabua, Derick A., Department of Arts Education University of Calabar, Calabar. Nigeria. 
provide quality basic education for learners. However, education in the world over, and Nigeria in particular is an instrument for affecting the development of its citizens. In fact, it is said to be an instrument par excellence fornational development (National Policy on Education, FRN, 2004). It is also a vital tool for socio-economic, political and technological development. In Nigeria like in other countries, educationhas remained an instrument for change. For instance,the Punch online newspaper of June, 20,2018 reported that of the $\mathrm{N} 9,120,334,988,225$ budget passed by the senate, N102.907bn was allocated to education which has however, been described by stakeholders as not good enough.

However, accordingto an erstwhile Minister of Education, funding is not Nigeria's main problem (Abayomi, 2013).Evidence, the author wrote supported this because in 2006, the budgetary trend for educationsector was analysed which showed an incredulous inverse relationship between more budgetallocation and performance of pupils and students. The former Minister was quoted as saying that the more the budget of a given year to thesector, the lower the academic achievement of learners at both state and federal levels. The Nigerian language policy has made provisions for both internal and internationalcommunication. French is one of the international languages mostly used in commerce, scientificand technological research, administration, education etc. With the knowledge of this language,Nigeria and francophone countries would be able to work together in the above mentionedcapacities.

The Nigerian government appreciates the importance of language as a means ofpromotingsocial interaction and national cohesion; it thus encourages every child to learn asidethe language of the immediate environment, French language for smooth interactions withneighbours. Accordingly, French language was made compulsory at the Middle and Upper BasicEducation level. This however cannot be achieved if French teachers are not adequatelyemployed and if those employed are not encouraged to effectively teach the language.In the Nigerian education continuum, Middle Basic Education as the foundation requiresa sound knowledge of the French language, thus enriching pedagogical curriculum wassuggested as a strategy to be aggressively pursued to facilitate the successful achievement of theBasic Education objectives. French language introduced into the curriculum has necessitated theneed for more French language teachers with relevant communicative and collaborativecompetencies and skills in the language as those emphasized by the Social Computing theory.

There are several reports in the country's newspapers that constitute strong evidence of acrisis in the education sector at all levels: from primary through tertiary education. Educationalpractitioners at all levels need to constantly engage in a process that systematically andobjectively determine the relevance, effectiveness and impact of instructional activities at theselevels, in the light of stated objectives.In responding to the issues, the National Council on Education, which is the highestpolicy making body in Nigeria, mandated the Nigeria Educational Research and DevelopmentCouncil (NERDC) to produce a viable curriculum to meet national and internationaldevelopmental goals.

This education curriculum is structured into four levels:

1. Lower Basic Education (Primary 1-3)

2. Middle Basic Education (Primary 4-6)

3. Upper Basic Education (JSS 1-3)

4. Senior Secondary School (SSS 1-3)

This curriculum did not only update the old contents, but also introduced newsubjects and associated skills requirements. The subjects were divided into 'core', 'compulsory'and 'elective'. By this policy, French language was introduced as a core subject from primary (which is the beginning of the Middle Basic Education) and its teaching was expected to belearnercentred, activity based and current terminologies introduced. However, there are lots ofproblems pointed out by experts in curriculum practice. In view of the complaints about thecurriculum, the Federal Government ordered a comprehensive review of the Basic EducationCurriculum.

This policy and its implementation was expected to have yielded positive fruit at theMiddle Education level where French language was introduced, but there seem to bedissatisfaction still in some quarters; thus the purpose of this study which examines the NationalCurriculum for the Middle Basic Education programme with emphasis on French language(Igbokwe, 2015). The purpose of this work was not only to create awareness on the need to carry out a validcurriculum review, but more importantly, to derive a baseline data on current state of Frenchlanguage education from 
the reactions of a representative sample of teachers as stakeholders ineducation.

\section{Theoretical framework}

Social computing theory serves as a background to this study because it is a broad researcharea situated at the intersection of computer science, economics and other social sciences. Itconcerns both harnessing human intelligence for computational tasks and the design ofcomputational systems that support social behaviour and interaction (CRCS, 2016). This implies that when approximately combined, social computing applications provideopportunities to facilitate classroom communications and collaboration; and ultimately, enhanceacademic achievement of learners. It emphasizes collaboration and enables learners to engage inproductive activities for their success.

\section{Problem statement}

French is the second official language in Nigeria, as well as a compulsory subject in the Middle and Upper-basic levels of education. Therefore, for the objectives of the language as a medium of communication, as well as a subject to be learnt in schools at the foundational level of education to be achieved, more efforts should be geared towards the quality of the curriculum content which has hitherto been perceived to be due for a review,in order to fit into the ever changing educational needs of the Nigerian people that is characterised by pedagogical innovations in line with ICT revolution. These innovations are meant to put the learners at the centre of the learning process; thereby, making them to learn by practicing, which is not only peculiar to languages, but also to other educational endeavours.

\section{Purpose of study}

The main purpose of this study was to investigate how quality can be achieved in Frenchlanguage classrooms in the South-South geo-political zone of Nigeria, through seeking awareness of somespecific learner-centred educational practices themes.

\section{Research question}

The research question raised to guide the study was: What learner-centred educationalpractices can contribute to understanding of the current structure of the French languagecurriculum at the Middle Basic Education?

\section{Methods and procedure}

The study examined responses from teachers in South-South States of Nigeria on issuesfacing the Middle Basic Education curriculum, as well as reflects on the dynamics ofameliorating some of the difficulties posed. The Qualitative technique was used to elicitinformation from teachers of French language that numbered 180 . These teachers were randomlysampled from about 802 Basic Education teachers of French language in the study area.Theseteachers were randomly sampled from the six groups of teachers comprising 30 from each Statein the zone.They were judged adequate representative of the study because they were in contact with thelearners at the implementation stage of the educational system and were capable of discussingand responding to various curriculum issues in their focus group discussion.

Group discussionswere on specific curriculum themes emphasizing learner-centred educational practices such as:

1. Emphasizes deep rather than broad coverage

2. Emphasizes problem-solving that stresses skills development as well as knowledge acquisition

3. Providing for individual differences.

4. Is responsive to emerging issues such as HIVIAIDS, conflict resolution etc

5. Provides for grade-level appropriate strategies 6. Is properly sequenced.

7. Emphasizes use of ICT for teaching and learning

The 6 zones represented the 6 groups used and their submissions were acknowledged andused in the discussion of findings.

\section{Findings}

The questions for discussion in each group were the same as follows: Does the presentMiddle Basic Education curriculum adequately emphasize or provide for (a) deep rather thanbroad coverage? (b) problem-solving that stresses skills development as well as knowledgeacquisition? (c) individual differences? (d) emerging issues such as HIVIAIDS, conflictresolution etc? (e) grade-level appropriate strategies? (f) proper sequencing? (g) use of ICT forteaching and learning?During discussions, sampled groups agreed that, in theory as well as practice, the Frenchlanguage curriculum adequately emphasize broad coverage, is 
responsive to emerging issues, provides for grade-level appropriate strategies, and is properly sequenced. However, it does notemphasize problem-solving that stresses skills development as well as knowledge acquisition;does not provide for individual differences and does not emphasize use of ICT in teaching andlearning at the level under study.

\section{Discussion}

Teachers used agreed that learnercentred educational practices must be encouraged. Thisis in consonance with Wikipedia (2015 b) which insisted that curriculum needs to put learnersinterest first, acknowledging that learners voice is central to the learning experience. From theresults of the analysis of findings, group members asserted that the aspects of the curriculum andpractices not given adequate attention to make learners of this very important languageassimilate appropriately into the academic culture, and be able to contribute meaningfully toknowledge bank must be revisited by the authority concerned.

The reasons given for thisnegligence were that there was no enabling environment created to stimulate teachers'commitment to teaching French language. The curriculum, they said, does not give room forcreativity and opportunity for learners to excel. It was said to be stereotyped and made thelessons boring.

The second reason was that of lack of modern facilities for advancement even at this veryimportant level of introducing the language, and due to this, the curriculum was said to beteacher-centred. Learning was based on rote/memorization as a result of the large class sizes.Whereas, no language laboratories were said to be in schools, thus learning was not put intopractice. This was not good enough as teachers agreed with Ability English YouTube Channel(2015) that language is about dealing with the world. It is a purposeful activity and thattextbooks alone can be quite sterile. With computers, internet connectivity and projectors, trainedteachers can bring the actual world-its images and sounds- into the classroom.

Thirdly, the absence of properly trained teachers further obstructed the process ofteaching French at the Middle Basic education as proposed by the government. Teacherscontinued to use traditional lecture methods of teaching in the very few schools where they werefound, and rarely were ICT used. Whereas teachers are looked up to and are considered asmodern heroes. The roles teachers play in teaching makes it important for them to receiveadequate training before they can teach (Technology, 2015). In addition Field (2004) stated thatlanguage teaching has not seen as much benefit from technology as might be expected. Theprincipal reason the author proffered was that of attitude and a concomitant failure to act inappropriate ways and apply appropriate procedures as equally emphasized by the SocialComputing theory.

\section{CONCLUSION}

The French language curriculum in Nigeria and particularly at the Middle Basic Education calls for more attention by all stakeholders in education. Many aspects of contents and practices by teachers must be given adequate consideration to make learners of this very important language assimilate appropriately into the academic culture, and be able to contribute meaningfully to knowledge bank.

\section{RECOMMENDATIONS}

The major recommendation which was made based on the findings of the study was thatlearner-centred educational practices must be encouraged by making sure that the Frenchlanguage curriculum at this very important level, that is, the Middle Basic Education levelwhichis perceived to be inadequate, needs to be reviewed. If this is done, it will reflect more learner-centrededucational practices like those emphasizing deep coverage of contents, use of ICT in teaching,providing for problem-solving that uses skills development and pays attention to individualdifferences.

Secondly, government should endeavour to train more teachers of French language forthis level of teaching. This can be done by lowering a little bit the entry qualification, intoinstitutions of higher learning, of those who show interest in becoming teachers of the language.

Thirdly, the government should endeavour to build and equip language laboratories in the primary schools with state-ofthe-art ICT facilities like computers, televisions, audio-players, projectors etc. This provision will enable learners develop and improve on their proficiency of the language as well as the interest in the language. 


\section{REFERENCES}

Abayomi, A., 2013. Accountability, not more money needed to fix education. Vanguard

News.

May

30.www.vanguardngr.com/.../accountabil ity...

Ability English YouTube Channel, 2015. www.ability.edu.au/why/.../modern facilities

Centre for Research on Computing and Society 920160. Theory and applications of

social computing. http:// www.crcs.seas.harvard.edu/theory-and-

Emeh, J. U; Isangedighi, A. J; Asuquo, P; Kalu, I; and Ogaboh, A. M., 2011. Curriculum Review: Reactions from education stakeholders in South-South States of Nigeria. Global Journal of Human Social Science, 11, 2

Federal Republic of Nigeria 2004. National Policy on Education. Lagos: Federal Government of Nigeria (FGN).

Field, K., 2004. Issues in modern foreign languages teaching. UK: Routledge. ISBN:

1134581041, 9781134581047

Igbokwe, C., 2015. Recent curriculum reforms at the basic education level in Nigeria aimed at catching them young to create change. American Journal of Educational Research 3,1, 31-37.

Ogochukwu, O., 2001. Press conference address by the Ex-chairman of Niger-Delta Development Commission to formally announce the international conference on the development of the Niger Delta Region on Thursday, September 20, 2001.11

Punch online newspaper, June, 20, 2018

Suarez-Orozco and Sattin 2007. World youth report 2007: Young people's transition to adulthood.

https//books.google.com/books. ISBN:9211302579teAchnology 2015. Are teachers adequately trained to perform their jobs? www.teachnology.com/.../education/

The Free Library 2012. http: www. the free library. com/Measuring + the acceptability of French language as a second language by Nigerians.

Wikipedia,

2015a. http://www.punching.com/news/constituti on-6-geopolitical zonesdivide-northsouth.

Wikipedia 2015 b. Student-centred learning. https://en.m.wikipedia.org/.../ 